GPJI 3(2)(2019) Gelanggang Pendidikan Jasmani Indonesia

\title{
PERBEDAAN TINGKAT KEBUGARAN JASMANI DAN KECEPATAN TENDANGAN ANTARA ATLET PENCAK SILAT PERSAUDARAAN SETIA HATI TERATE (PSHT) UNIT KEGIATAN MAHASISWA (UKM) UNIVERSITAS NEGERI MALANG DAN UNIVERSITAS BRAWIJAYA
}

\author{
Rizal Amirudin ${ }^{1}$, Mu' $^{\prime}$ arifin $^{2}$ \\ Universitas Negeri Malang \\ rizalamirudin94@gmail.com
}

\begin{tabular}{l}
\hline Info Artikel \\
\hline Sejarah Artikel: \\
Diterima: September-2019 \\
Disetujui: Desember-2019 \\
Dipublikasikan : Desember-2019 \\
\hline Kata Kunci: \\
pengembangan, multimedia \\
interaktif, latihan kekuatan \\
\hline
\end{tabular}

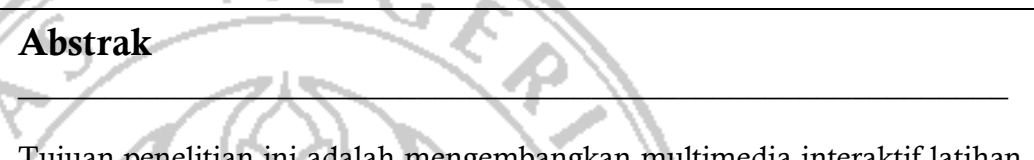

Tujuan penelitian ini adalah mengembangkan multimedia interaktif latihan kekuatan menggunakan latihan beban untuk mengatasi masalah yang muncul dalam perkuliahan spesialisasi kondisi fisik dasar. Data dikumpulkan dengan menggunakan analisis kebutuhan menggunakan angket kepada 28 orang mahasiswa pendidikan kepelatihan olahraga. Hasil pengembangan produk multimedia interaktif latihan kekuatan pada matakuliah spesialisasi kondisi fisik dasar diperoleh hasil sebagai berikut: hasil evaluasi ahli kepelatihan $87,33 \%$, hasil evaluasi ahli media $81,82 \%$, hasil uji coba kelompok kecil $89,6 \%$ hasilnya baik, hasil uji coba kelompok besar $90,07 \%$ hasilnya sangat baik. Sehingga produk ini layak untuk digunakan.

\section{Abstract}

This research is conducted with the aim of developing the strenght training use weight training to overcome problems that arise in lectures specializing in basic physical conditions. Data were collected using a needs analysis using a questionnaire to 28 college student. The result of product interactive multimedia strength training in lectures specializing in basic physical conditions obtained the results: the result evaluation of coaching expert $87,33 \%$, the result evaluation of media expert $81,82 \%$, small group trial $89,6 \%$ it implies good result, large group trial 90,07 it shows very good result. So this product is fit for use.

(C) 2019 Universitas Negeri Malang 


\section{PENDAHULUAN}

Olahraga adalah suatu bentuk aktifitas fisik yang terencana dan terstruktur yang melibatkan gerakan tubuh berulang-ulang dan ditujukan untuk meningkatkan kebugaran jasmani. Undang Undang Nomor 3 Tahun 2005 menyebutkan, bahwa olahraga adalah segala kegiatan yang sistematis untuk mendorong, membina, serta mengembangkan potensi jasmani, rohani, dan sosial. Olahraga memiliki banyak manfaat, selain dapat menyehatkan jasmani juga dapat meningkatkan dan mempertahankan kebugaran jasmani. Kegiatan olahraga setiap orang berbeda tergantung tujuan yang ingin dicapai. Jenis olahraga berdasarkan sifat dan tujuannya terbagi menjadi empat jenis, salah satunya adalah olahraga prestasi yaitu salah satu jenis olahraga yang bertujuan untuk mencapai sebuah pencapaian prestasi (Giriwijoyo, 2013:37).

Di Indonesia terdapat bermacam-macam cabang olahraga prestasi yaitu, sepakbola, bolavoli, bolabasket, tenis meja, tenis lapangan, bulutangkis, atletik, renang, senam, dan beladiri. Salah satu olahraga beladiri yang digemari dan sering dipertandingkan adalah pencak silat yang merupakan budaya asli bangsa Indonesia. Para pakar pencak silat meyakini bahwa masyarakat Melayu menciptakan dan menggunakan ilmu bela diri sejak jaman prasejarah, karena pada masa itu manusia harus menghadapi alam yang keras dengan tujuan mempertahankan kelangsungan hidupnya dengan melawan binatang ganas dan berburu yang pada akhirnya manusia mengembangkan gerak-gerak bela diri (Lubis \& Wardoyo, 2014:1).

Istilah pencak silat mulai dipakai sejak berdirinya organisasi pencak silat di Indonesia yang disebut dengan Ikatan Pencak Silat Indonesia (IPSI) yang didirikan pada tanggal 18 Mei 1948 di Surakarta, diprakarsai oleh Mr. Wongsonegoro, yang saat itu menjabat sebagai ketua pusat kebudayaan Kedu (Lubis \& Wardoyo, 2014:3). Pencak silat mulai berkembang ke mancanegara terbukti dengan didirikannya Persekutuan Pencak Silat Antar Bangsa (PERSILAT) yang beranggotakan 4 negara yaitu Indonesia, Malaysia, Singapura, dan Brunei Darussalam. Sejak saat itu pencak silat bukan hanya digunakan sebagai olahraga beladiri tapi juga disebut sebagai olahraga prestasi karena mulai dipertandingkan secara resmi.

Pencak silat sebagai olahraga prestasi sering dipertandingkan baik tingkat kabupaten, provinsi, nasional maupun Internasional. Menurut Rahayuni (2014:60), pertandingan pencak silat dibagi menjadi 4 kategori yaitu: (1) kategori tanding; (2) kategori seni tunggal; (3) kategori seni ganda; dan (4) kategori seni regu serta digolongkan berdasarkan jenis kelamin dan umur.

Pencak silat sering dipertandingkan, baik dalam single event seperti Kejuaraan Daerah (Kejurda) maupun multi event seperti Pekan Olahraga Provinsi (PORPROV), Pekan Olahraga Pelajar Daerah (POPDA), dan Pekan Olahraga Mahasiswa Daerah (POMDA). POMDA adalah kegiatan olahraga yang mempertandingkan cabang olahraga pencak silat antar mahasiswa yang diikuti oleh Perguruan Tinggi Negeri (PTN) maupun Perguruan Tinggi Swasta (PTS) tingkat provinsi. Perguruan tinggi yang mengikuti kegiatan POMDA diantaranya adalah Unevirsitas Negeri Malang (UM) dan Universitas Brawijaya (UB).

UM adalah salah satu Perguruan Tinggi Negeri (PTN) di Jawa Timur yang mengembangkan olahraga pencak silat. Olahraga prestasi pencak silat di UM dikembangkan melalui UKM pencak silat yang terdiri dari berbagai perguruan pencak silat yaitu Tapak Suci (TS), Nur Harias (NH), Perisai Diri (PD), Merpati Putih (MP), dan Persaudaraan Setia Hati Terate (PSHT). Pembinaan prestasi pencak silat dilakukan dengan mengadakan kegiatan latihan rutin dengan tujan agar mahasiswa dapat mengembangkan bakat dan kemampuaannya di luar bidang akademik dan berprestasi secara optimal di bidang non akademik. Untuk mengirimkan delegasi yang akan dipertandingkan di event POMDA, seleksi intern di UM dilaksanakan antar perguruan yang tergabung dalam UKM pencak silat. Seleksi ini dapat diikuti oleh seluruh mahasiswa yang menjadi anggota UKM pencak silat dari berbagai fakultas.

UB adalah salah satu Perguruan Tinggi Negeri (PTN) di Jawa Timur khususnya di Kota Malang yang juga mengembangkan olahraga pencak silat, yang diwadahi dalam suatu Unit Kegiatan Mahasiswa (UKM), diantaranya UKM Persaudaraan Setia Hati Terate (PSHT), Perisai Diri (PD), dan Tapak Suci (TS). Pembinaan prestasi pencak silat dilakukan dengan mengadakan kegiatan latihan rutin dengan dengan jadwal yang telah ditentukan.

Salah satu cabang pencak silat yang menjadi sorotan diantara kedua perguruan tinggi adalah Pencak Silat Persaudaraan Setia Hati Terate (PSHT), yang memiliki beberapa prestasi. Menurut Harsono (2015:4) prestasi olahragawan ditentukan oleh faktor fisik, teknik, taktik, dan mental. Namun teknik, taktik, dan mental tidak dapat dicapai jika olahragawan tidak memiliki kondisi fisik yang baik, jadi untuk mendapatkan teknik atau taktik, dan strategi yang baik maka diperlukan kondisi fisik yang 
baik pula. Kondisi fisik sangat menentukan dalam mendukung tugas olahragawan dalam pertandingan sehingga dapat tampil secara maksimal. Kondisi fisik seseorang dapat dilihat dari kebugaran jasmaninya.

Menurut Irianto (2004:2) kebugaran adalah kebugaran fisik (physical fitness), yaitu kemampuan seseorang melakukan kerja sehari-hari tanpa timbul kelelahan yang berlebihan sehingga masih dapat menikmati waktu luangnya. Kemudian untuk mendapatkan kebugaran yang memadai diperlukan perencanaan sistematik melalui pemahaman pola hidup sehat meliputi makan, istirahat, dan olahraga. Tingkat kebugaran seseorang dapat diketahui dengan melakukan tes kebugaran jasmani. Terdapat berbagai macam tes kebugaran jasmani yang dapat digunakan salah satunya yaitu tes kebugaran jasmani versi Multi Stage Fitnes Test atau bisa juga sisebut Bleep Test.

Berdasarkan dari hasil wawancara pada tangal 19 februari 2019 dengan pelatih UKM PSHT UM mengatakan jumlah atlet keseluruhan 33 atlet terdiri dari 6 putri dan 27 putra, latihan satu minggu 3 kali dimulai pukul 19.00-12.00, Ada latihan tambahan diluar jadwal latihan yang ditentukan, Kondisi fisik / kebugaran jasmani variasi ada yang bagus dan ada yang kurang bagus, Teknik yang sering digunakan saat pertandingan pukulan dan tendangan. Sedangan UKM PSHT UB mengatakan Jumlah atlet keseluruhan 30 atlet terdiri dari 4 putri dan 26 putra, Latihan satu minggu 3 kali dimulai pukul 19.00-12.00, Ada latihan tambahan diluar jadwal latihan yang ditentukan, Kondisi fisik / kebugaran jasmani variasi ada yang bagus dan ada yang kurang bagus, Teknik yang sering digunakan saat pertandingan pukulan dan tendangan.

Berdasarkan hal tersebut, peneliti dengan dibantu oleh 2 observer melakukan pengamatan sabung pada atlet UKM PSHT UM dan atlet UKM PSHT UB yang terdiri dari beberapa indikator, diantaranya: (1) Pukulan: sikap kaki kuda kuda kiri/kanan, kedua belah tangan bersiap depan dada, tangan yang akan memukul mengepal, tangan kiri/kanan memukul dengan mengubah kepalan telungkup, lakukan dengan mengubah posisi kaki ke depan, sasaran pukulan dari bawah leher sampai pinggang, (2) Tendangan: kaki kuda-kuda kiri/kanan, kaki kanan/kiri ditendangkan ke depan dengan hentakan telapak kaki sejajar dengan bahu (tendangan lurus), kaki kanan/kiri ditendangkan ke samping dengan hentakan punggung kaki (tendangan sabit), kaki kanan/kiri ditendangkan dari samping ke depan dengan hentakan telapak kaki (tendangan T), kedua tangan berada di depan dada sebagai penyeimbang, sasaran tendangan dari bawah leher sampai pinggang, (3) Sapuan: kaki kanan dijatuhkan sehingga lutut kanan menyentuh lantai dan kaki kiri ditekuk, tangan kiri menyentuh lantai dan pantat diangkat dan kaki kiri agak dimiringkan, kaki kiri ditarik direbahkan atau semprok dan kaki kanan ditarik, kaki kanan diayunkan ke arah depan dengan cepat dan kuat dengan posisi ujung kaki tendangan sabit atau bonggol, sapuan depan di arahkan kepada kaki lawan yang tidak melalukan tendangan atau kaki yang menjadi tumpuan saat lawan menendang. Bisa juga di arahkan pada saat lawan tidak melakukan tendangan atau serangan, dan di arahkan kepada kaki belakang dari kudakuda lawan untuk menambah efektivitas serangan, (4) Serkel: kaki kanan dijatuhkan sehingga lutut kanan menyentuh lantai dan kaki kiri ditekuk, posisi badan membelakangi lawan, tangan kiri menyentuh lantai dan pantat diangkat dan kaki kiri agak dimiringkan, kaki kiri ditarik direbahkan atau semprok dan kaki kanan ditarik, kaki kanan diayunkan ke arah belakang dengan cepat dan kuat dengan tungkai kaki, serkel di arahkan kepada kaki lawan yang tidak melalukan tendangan atau kaki yang menjadi tumpuan saat lawan menendang. Bisa juga di arahkan pada saat lawan tidak melakukan tendangan atau serangan, dan di arahkan kepada kaki belakang dari kuda-kuda lawan untuk menambah efektivitas serangan, (5) Guntingan: bersiap dengan kaki kuda-kuda kiri/kanan depan, menjatuhkan lawan dengan menjepit kedua tungkai kaki pada sasaran leher pinggang atau tungkai lawan sehingga lawan jatuh, (6) Bantingan: bersiap dengan kaki kuda-kuda kiri/kanan depan, ketika lawan menendang, egos ke arah kanan/kiri diikuti tangkapan dalam, badan sedikit mengendap ke dalam, kaki kanan/kiri melangkah ke depan dengan diikuti kaki kanan/kiri, mengungkit kaki penumpu lawan dari arah dalam ke belakang tumit, sekaligus tangan kanan mendorong tubuh lawan, Setelah lawan terjatuh, posisi kaki seperti kuda kuda samping. Berikut data hasil observasi yang didapat. 
Tabel 1. Data Hasil Pengamatan Sabung UKM PSHT UM

\begin{tabular}{lllll}
\hline No & Teknik & Total intensitas & Benar & Salah \\
\hline 1 & Pukulan & 51 & $73 \%$ & $27 \%$ \\
2 & Tendangan & 107 & $78 \%$ & $22 \%$ \\
3 & Sapuan & 7 & $43 \%$ & $57 \%$ \\
4 & Sirkel & 8 & $75 \%$ & $25 \%$ \\
5 & Guntingan & 5 & $40 \%$ & $60 \%$ \\
6 & Bantingan & 21 & $67 \%$ & $33 \%$ \\
\hline
\end{tabular}

Tabel 2. Data Hasil Pengamatan Sabung UKM PSHT UB

\begin{tabular}{lllll}
\hline No & Teknik & Total intensitas & Benar & Salah \\
\hline 1 & Pukulan & 61 & $70 \%$ & $30 \%$ \\
2 & Tendangan & 89 & $75 \%$ & $25 \%$ \\
3 & Sapuan & 0 & $0 \%$ & $0 \%$ \\
4 & Sirkel & 0 & $0 \%$ & $0 \%$ \\
5 & Guntingan & 2 & $100 \%$ & $0 \%$ \\
6 & Bantingan & 8 & $62 \%$ & $38 \%$ \\
\hline
\end{tabular}

Melihat hasil dari pengamatan sabung pencak silat UKM PSHT UM dan UKM PSHT UB bahwa serangan yang paling dominan sering dikeluarkan pada saat sabung adalah tendangan, dengan persentase kebenaran 78\% dari intensitas 107 tendangan untuk UKM PSHT UM sedangkan untuk UKM PSHT UB persentase kebenaran $75 \%$ dari intensitas 89 tendangan.

Berdasarkan hasil wawancara dan observasi diatas, peneliti ingin mengetahui perbedaan kecepatan tendangan dan kondisi fisik/kebugara jasmani UKM PSHT UM dan UB. Kebugaran jasmani memiliki beberapa faktor yang mempengaruhi, salah satunya adalah aktivitas fisik dan intensitas latihan. Berdasarkan penelitian yang telah dilakukan oleh Wardani (2017:67) tentang "Perbedaan Tingkat Kebugaran Jasmani Antara Olahragawan Pencak Silat Fakultas Ilmu Keolahagaan dan Olahragawan Unit Kegiatan Mahasiswa Pencak Silat Universitas Negeri Malang" menyatakan bahwa ada perbedaan yang signifikan antara kebugaran jasmani olahragawan pencak silat FIK dan olahragawan UKM pencak silat UM.

Berdasarkan latar belakang yang telah dijelaskan di atas, maka peneliti tertarik untuk melakukan penelitian bentuk studi komparatif dengan judul "Perbedaan Tingkat Kebugaran Jasmani dan Kecepatan Tendangan antara Atlet Pencak Silat UKM PSHT Universitas Negeri Malang dan Atlet Pencak Silat UKM PSHT Universitas Brawijaya". Tujuan dari penelitian yang dilakukan adalah: (1) untuk mengetahui tingkat kebugaran jasmani atlet pencak silat UKM PSHT UM, (2) untuk mengetahui tingkat kebugaran jasmani atlet pencak silat UKM PSHT UB, (3) untuk mengetahui perbedaan kebugaran jasmani antara atlet pencak silat UKM PSHT UM dan olahragawan pencak silat PSHT UB, (4) untuk mengetahui kecepatan tendangan yang dimiliki atlet pencak silat UKM PSHT UM, (5) untuk mengetahui kecepatan tendangan yang dimiliki atlet pencak silat UKM PSHT UB, (6) untuk mengetahui perbedaan kecepatan tendangan yang dimiliki antara atlet pencak silat UKM PSHT UM dan olahragawan pencak silat UKM PSHT UB.

\section{METODE}

\section{Rancangan Penelitian}

Ditinjau dari masalah yang diteliti, metode penelitian yang digunakan dalam penelitian ini adalah metode survei. Metode survei digunakan untuk mendapatkan data dari tempat tertentu yang alamiah (bukan buatan), tetapi peneliti melakukan perlakuan dalam pengumpulan data (perlakuan tidak seperti dalam eksperimen), misalnya kuesioner, tes, dan wawancara (Sugiyono, 2014:12).

Ditinjau dari tujuan penelitian, penelitian ini termasuk jenis penelitian kausal komparatif. Winarno (2017:63) menjelaskan penelitian kausal komparatif bertujuan untuk mengungkapkan kemungkinan adanya hubungan sebab-akibat antar variabel tanpa memanipulasi suatu variabel. Artinya, variabel-variabel yang akan diuji hubungan kausalnya telah terjadi dalam kondisi yang wajar.

Variabel yang diteliti berupa variabel tergantung yang meliputi: (1) tingkat kebugaran jasmani atlet pencak silat unit kegiatan mahasiswa persaudaraan setia hati terate (UKM PSHT) universitas negeri malang (UM); (2) tingkat kebugaran jasmani atlet pencak silat unit kegiatan mahasiswa persaudaraan setia hati terate (UKM PSHT) universitas brawijaya (UB); (3) kecepatan tendangan 
yang dimiliki atlet pencak silat unit kegiatan mahasiswa persaudaraan setia hati terate (UKM PSHT) universitas negeri malang (UM); dan (4) kecepatan tendangan yang dimiliki atlet pencak silat unit kegiatan mahasiswa persaudaraan setia hati terate (UKM PSHT) universitas brawijaya (UB).

\section{Data Penelitian}

Penelitian ini dilaksanakan di tempat yang sama yaitu di Stadion Cakrawala Universitas Negeri Malang dengan melaksanakan tes kebugaran jasmani versi multi stage fitness test atau bleep test dan pengukuran kecepatan tendangan pencak silat secara bersama-sama oleh atlet pencak silat UKM PSHT UM dan atlet pencak silat UB pada hari Minggu mulai bulan april 2019 selama satu bulan penuh.

Subjek penelitian ini yaitu atlet pencak silat UKM PSHT UM berjumlah 30 orang dan atlet pencak silat UKM PSHT UB berjumlah 30 orang, sehingga total subjek berjumlah 60 orang.

Instrumen penelitian adalah suatu alat yang digunakan mengukur fenomena alam maupun sosial yang diamati (Sugiyono, 2014:148). Sedangkan menurut Winarno (2017:99), instrumen penelitian adalah alat-alat yang digunakan untuk memperoleh atau mengumpulkan data dalam rangka memecahkan masalah penelitian atau mencapai tujuan penelitian. Instrumen penelitian dalam pendidikan jasmani dan olahraga dapat dibedakan menjadi dua yaitu tes dan non tes. Tes merupakan instrumen yang berfungsi untuk mengumpulkan data berupa pengetahuan maupun keterampilan seseorang dengan menggunakan skala atau angka tertentu (Winarno,2017:101). Instrumen tes yang digunakan dalam penelitian ini adalah tes kebugaran jasmani versi multi stage fitness test atau bleep test dan tes kecpatan tendangan sebagai berikut: (a) tes multi stage fitness test atau bleep test, lari bolak balik 20 meter putra putri, bertujuan untuk mengetahui daya tahan, (b) instrumen tes yang digunakan untuk mengetahui kecepatan tendangan, meliputi: tes tendangan sabit 10 detik ditujukan untuk mengetahui kecepatan tendangan kaki kanan dan kiri, tes tendangan lurus 10 detik ditujukan untuk mengetahui kecepatan tendangan kaki kānan dan kiri, tes tendangan samping 10 detik ditujukan untuk mengetahui kecepatan tendangan kaki kanan dan kiri. Nilai koefisien validitas dan reliabilitas diambil melalui sempel atlet platnas tahun 1999 sd 2005, dengan nilai reliabilitas 0.87 dan validitas isi dengan face validity (Lubis \& wardoyo, 2016:198).

\section{Teknik Pengumpulan Data}

Teknik yang digunakan oleh peneliti dalam pengumpulan data adalah dengan menggunakan teknik pengukuran bentuk tes yaitu tes kebugaran jasmani versi multi stage fitness test atau bleep test. Tes merupakan salah satu instrument yang dapat digunakan sebagai dasar dalam memberikan penilaian (evaluasi) pada peserta didik terhadap materi yang diberikan baik materi teori maupun materi praktek dalam domain psikomotorik. Tes sebagai alat untuk memperoleh informasi tentang karakteristik peserta didik atau sifat suatu objek (Nurrochmah, 2016:7). Tes yang dilakukan yaitu tes kebugaran jasmani versi multi stage fitness test atau bleep test dilengkapi dengan petunjuk pelaksanaan tes. Langkahlangkah yang dilakukan dalam tahap pengumpulan data yaitu tahap persiapan, tahap pelaksanaan, dan tahap pelaporan hasil penelitian: (a) tahap Persiapan: studi pendahuluan yang dimaksud disini adalah menentukan permasalahan yang akan diteliti, menentukan populasi dan sampel penelitian yaitu berupa lokasi penelitian dan subjek penelitian, mengurus surat ijin penelitian, menyusun instrumen tes, mempersiapkan fasilitas dan alat tes, mempersiapkan tenaga pembantu lapangan, memberi arahan pada pembantu lapangan, memberi petunjuk kepada olahragawan pencak silat UKM PSHT UM dan UKM PSHT UB, mengatur jadwal pelaksanaan tes, (b) tahap pelaksanaan tes.

Tahap pelaksanaan tes kebugaran jasmani dalam penelitian ini terdiri dari dua tes yaitu tes kebugaran jasmani versi multi stage fitness test atau bleep test dan tes pengukuran kecepatan tendangan pencak silat. Adapun pelaksanaan tes tersebut sebagai berikut: (1) tes Kebugaran Jasmani versi multi stage fitness test atau bleep test. Tes ini dilakukan dengan lari bolak-balik 20 meter putra putri. Tahap pertama untuk tes lari bolak-balik 20 meter yaitu menyiapkan alat dan fasilitas yang meliputi: (a) lapangan yang tidak licin sepanjang 22 meter atau lebih, (b) stopwatch, (c) sound sitem, (d) nomer dada, (e) pita kaset, (f) meteran untuk membuat lintasan. Persiapan test, (a) panjang lintasan yang yang standart adalah 20 meter, lebar tiap lintasan antara 1-1,5 meter, (b) lakukan pemanasan peregangan dan gerakan angota tubuh dan tungkai, (c) jangan makan 2 jam sebelum tes, (d) gunakan pakaian olahraga, (e) hindari merokok/alcohol sebelum melakukan tes, (f) jangan melakukan tes sesudah latihan berat, (2) tahap pelaksanaan tes meliputi: (a) cek bahwa bunyi dua bleep test yang menjadi standar untuk pengukuran lapangan adalah satu menit (enam puluh detik), apabila kaset telah meregang/mulur atau menyusut maka pembuatan lapangan mengacu pada tabel standart kecepatan 
putaran kaset, (b) testi harus berlari dan menyentuhkan/menginjakkan salah satu kaki pada garis akhir dan berputar untuk kembali berlari setelah bunyi bleep terdengar (tunggu sampai bunyi bleep terdengar), (c) lari bolak-balik terdiri dari beberpa tingkatan. Setiap tingkatan terdiri dari beberpa balikan ditandai dengan bunyi "bleep" sebanyak tiga kali, sedangkan setiap balikan ditandai dengan bunyi "bleep", (d) testi dianggap tidak mampu apa bila dua kali berturut-turut tidak dapat menyentuh/menginjakkan kakinya pada garis.

Pengukuran Kecepatan Tendangan Pencak Silat: (1) tes kecepatan teknik tendangan lurus, tahap pertama dalam tes ini adalah menyiapkan alat dan fasilitas yaitu: (a) target (hand box); (b) meteran;

(c) stopwatch; dan (d) nomer dada. Selanjutnya tahap kedua menyiapkan petugas tes, mengukur ketinggian target, pencatat waktu, dan pemegang target. Tahap terakhir yaitu memimpin pelaksanaan pemanasan, pelaksanaan tes pengukuran kecepatan tendangan depan, mengamati jalanya pelaksanaan, memandu lamanya tes, dan mencatat hasil tes, (2) tes kecepatan teknik tendangan sabit, tahap pertama dalam tes ini adalah menyiapkan alat dan fasilitas yaitu: (a) target (hand box); (b) meteran;

(c) stopwatch; dan (d) nomer dada. Selanjutnya tahap kedua menyiapkan petugas tes, mengukur ketinggian target, pencatat waktu, dan pemegang target. Tahap terakhir yaitu memimpin pelaksanaan pemanasan, pelaksanaan tes pengukuran kecepatan tendangan depan, mengamati jalanya pelaksanaan, memandu lamanya tes, dan mencatat hasil tes, (3) tes kecepatan teknik tendangan samping, tahap pertama dalam tes ini adalah menyiapkan alat dan fasilitas yaitu: (a) target (hand box); (b) meteran; (c) stopwatch; dan (d) nomer dada. Selanjutnya tahap kedua menyiapkan petugas tes, mengukur ketinggian target, pencatat waktu, dan pemegang target. Tahap terakhir yaitu memimpin pelaksanaan pemanasan, pelaksanaan tes pengukuran kecepatan tendangan depan, mengamati jalanya pelaksanaan, memandu lamanya tes, dan mencatat hasil tes.

\section{Tahap Pelaporan Hasil Penelitian}

Tahap pelaporan hasil dalam penelitian ini akan dilakukan dengan cara: (1) mengumpulkan formulir tes perorangan atau gabungan, (b) skor hasil tes dianalisis menggunakan analisis data Stastitical Package for the Social Sciences (SPSS) versi 25, (c) hasil dari hasil analisi data kemudian disampaikan secara deskriptif.

\section{Analisis Data}

Berdasarkan pada tujuan penelitian serta pertimbangan dengan jenis data yang telah terkumpul telah diperoleh data berdistribusi normal dengan hasil uji normalitas yang diperoleh berupa Lhitung < Ltabel $\alpha 0,05$, maka prosedur analisis yang digunakan adalah uji beda menggunakan teknik statistika inferensial bentuk Independent Sample T-test. Sedangkan jika jenis data yang terkumpul telah diperoleh data berdistriusi tidak normal dengan hasil uji normalitas yang diperoleh berupa Lhitung $>$ Ltabel $\alpha$ 0,05 , maka prosedur analisis yang digunakan adalah uji beda menggunakan teknik statistika inferensial bentuk Mann-whitney Test. Sebelum prosedur analisis data dilakukan, terlebih dahulu dilakukan uji persyarat yang harus dipenuhi dalam analisis uji-t. Adapun uji persyaratan yang diperlukan yaitu meliputi uji normalitas, untuk mengetahui bahwa data yang terkumpul merupakan data yang berasal dari sebaran normal, adapun teknik yang digunakan menggunakan uji Kolmogorov-Smirnov. Sedangkan untuk mengetahui apakah ragam varian dalam subjek homogenitas atau tidak maka diperlukan uji homogenitas menggunakan uji Fisher. Adapun prosedur analisis data dilakukan sebagai berikut.

\section{Uji Normalitas}

Uji normalitas data dilakukan sebagai prasyarat untuk melakukan uji perbedaan dan hasil uji prasyarat tersebut akan diketahui bahwa data setiap variabel yang akan dianalisis harus berdistribusi normal. Hal ini sesuai dengan pendapat Sugiyono (2014:271), "penggunaan statistik parametris mensyaratkan data dari variabel yang akan dianalisis harus berdistribusi normal, sehingga harus dilakukan pengujian normalitas data". Untuk bisa melakukan uji normalitas data diuji menggunakan teknik Kolmogorov-Smirnov. Uji kolmogorov-smirnov digunakan untuk menguji apakah distribusi sampel yang teramati sesuai dengan distribusi teoritis tertentu atau tidak (Quadratullah, 2014:218). Uji kolmogorov-smirnov beranggapan bahwa distribusi data yang diuji bersifat kontinyu dan sampel diambil dari populasi secara acak. Uji kolmogorov-smirnov dipakai jika sajian data berbentuk data tunggal 
(Djudin, 2013:2). Dengan adanya kriteria pengujian, jika $L_{\text {hitung }}<L_{\text {tabel }}$ artinya data berdistribusi normal dan jika sebaliknya, dan tidak berdistribusi normal, dengan menggunakan taraf signifikan $\alpha=0,05$.

\section{Uji Homogenitas}

Uji homogenitas data menggunakan uji Fisher. Uji Fisher digunakan untuk menguji hanya pada 2 (dua) kelompok data. Dengan kriteria pengujian, $F_{\text {hitung }}<F_{\text {tabel }}:$ Ho diterima : varians dua kelompok sama (homogen). Dan jika sebaliknya, data tidak sama (tidak homogen). Uji homogenitas ini dilakukan dengan taraf signifikan $\alpha=0,05$.

\section{Analisis Uji-t}

Jika data yang diperoleh berdistribusi normal dapat menggunakan teknik statistika Independent sampel t-test yang digunakan untuk mengetahui ada atau tidaknya perbedaan rata-rata antara dua kelompok sampel yang tidak berhubungan. Dengan adanya kriteria pengujian, jika $t_{\text {hitung }}<t_{\text {tabel }}: H_{0}$ diterima : rata-rata skor dua kelompok sama. Sebaliknya jika $t_{\text {hitung }}>t_{\text {tabel }}: H_{0}$ ditolak : rata-rata skor dua kelompok berbeda secara segnifikan. Uji ini dilakukan dengan taraf signifikan $\alpha=0,05$.

\section{HASIL}

\section{Analisis Data}

Dalam penelitian tingkat kebugaran jasmani dan pengukuran kecepatan tendangan antara atlet pencak silat Unit Kegiatan Mahasiswa Universitas Negeri Malang (UKM UM) dan atlet pencak silat Unit Kegiatan Mahasiswa Universitas Brawijaya (UKM UB). Untuk tes kebugaran jasmani menggunakan multi stage fitness test atau bleep test dan pengukuran kecepatan tendangan meliputi: 1) tes tendangan sabit 10 detik ditujukan untuk mengetahui kecepatan tendangan kaki kanan dan kiri, 2) tes tendangan lurus 10 detik ditujukan untuk mengetahui kecepatan tendangan kaki kanan dan kiri, 3) tes tendangan samping 10 detik ditujukan untuk mengetahui kecepatan tendangan kaki kanan dan kiri.

Pelaksanaan tes kebugaran jasmani dan pengukuran kecepatan tendangan dilakukan pada waktu dan tempat yang sama yaitu pada bulan April 2019 di Stadion Cakrawala Universitas Negeri Malang. Tes dilakukan sesuai urutan tes dan dilakukan secara bergantian, yaitu: 1) multi stage fitness test atau bleep test, 2) tendangan sabit 10 detik kaki kanan dan 10 detik kaki kiri, 2) tendangan lurus 10 detik kaki kanan dan 10 detik kaki kiri, 3) tes tendangan samping 10 detik kaki kanan dan 10 detik kaki kiri. Tes ini bertujuan untuk mengetahui adakah perbedaan tingkat kebugaran jasmani dan kecepatan tendangan antara atlet pencak silat UKM UM dan atlet pencak silat UKM UB.

Hasil analisis data yang disajikan antara lain: (1) hasil analisis uji prasyarat dan (2) hasil analisis uji-t. Hasil analisis uji prasyarat terdiri dari (a) uji normalitas dengan menggunakan teknik uji Kolmogorov-Smirnov, (b) uji homogenitas. Hasil analisis uji-t menggunakan teknik independent sample ttest. Hasil analisis data yang telah dilakukan oleh peneliti akan dijelaskan sebagai berikut.

\section{Hasil Analisis Uji Normalitas}

Hasil statistik uji Kolmogorov-Smirnov untuk mengetahui normalitas data dengan taraf signifikan $\alpha=0,05$ akan disajikan pada Tabel 3 .

Tabel 3. Uji Normalitas Tes Kebugaran Jasmani Atlet UKM Pencak Silat UM dan UB

\begin{tabular}{lc}
\hline & One-Sample Kolmogorov-Smirnov Test \\
\hline Test Statistic &, 151 \\
Asymp. Sig. (2-tailed) &, $078^{\mathrm{c}}$ \\
\hline
\end{tabular}

Berdasarkan Tabel 3 di atas, pada uji normalitas diperoleh data sebagai berikut. Hasil perhitungan menggunakan SPSS 25 dinyatakan bahwa nilai perhitungan dengan uji one sample kolmogrov-smirnov dengan taraf signifikansi $\alpha=0,05$. Hasil kebugaran jasmani antara atlet UKM pencak silat UM adalah 0,151 dan UKM pencak silat UB adalah 0,078. Nilai ini lebih besar dari signifikansi $\alpha=0,05$, maka dapat disimpulkan hasil kebugaran jasmani antara atlet UKM pencak silat UM dan UKM pencak silat UB memiliki data yang normal.

Hasil statistik uji Kolmogorov-Smirnov untuk mengetahui normalitas data dengan taraf signifikan $\alpha=0,05$ akan disajikan pada Tabel 4 berikut. 
Tabel 4. Uji Normalitas Tes Kecepatan Tendangan Atlet UKM Pencak Silat UM dan UB

$\begin{array}{lll} & \text { One-Sample Kolmogorov-Smirnov Test } & 128\end{array}$

Asymp. Sig. (2-tailed)

, $200^{\mathrm{c}}$

Berdasarkan Tabel 4 di atas, pada uji normalitas diperoleh data sebagai berikut. Hasil perhitungan menggunakan SPSS 25 dinyatakan bahwa nilai perhitungan dengan uji one sample kolmogrov-smirnov dengan taraf signifikansi $\alpha=0,05$. Hasil tes kecepatan tendangan antara atlet UKM pencak silat UM 0,128 8dan UKM pencak silat UB adalah 0,200. Nilai ini lebih besar dari signifikansi $\alpha=0,05$, maka dapat disimpulkan hasil tes kecepatan tendangan antara atlet UKM pencak silat UM dan UKM pencak silat UB memiliki data yang normal.

\section{Hasil Analisis Uji Homogenitas}

Hasil analisis uji homogenitas menggunakan uji Fisher, penelitian kebugaran jasmani antara atlet UKM pencak silat UM dan UKM pencak silat UB akan dipaparkan pada Tabel 5 berikut.

Tabel 5. Uji Homogenitas Fisher Tes Kebugaran Jasmani Atlet UKM Pencak Silat UM dan UB

\begin{tabular}{ccc}
\hline Hasil Analisis & Nilai F Tabel & Keterangan \\
\hline 0,463 & 1,98 & F hitung $<\mathrm{F}$ tabel $\alpha=0,05$ artinya Varian Populasi \\
Homogen
\end{tabular}

Berdasarkan hasil hasil analisis data uji homogenitas kebugaran jasmani antara atlet UKM pencak silat UM dan UKM pencak silat UB menunjukkan F hitung 0,463 lebih kecil dari F tabel $\alpha=$ 0,05 yaitu 1,98 artinya varian populasi homogen. Oleh karena itu, analisis uji-t dapat dilanjutkan.

Hasil analisis uji homogenitas menggunakan uji Fisher, penelitian kecepatan tendangan antara atlet UKM pencak silat UM dan UKM pencak silat UB akan dipaparkan pada Tabel 6berikut.

Tabel 6. Uji Homogenitas Fisher Tes Kecepatan Tendangan Atlet UKM Pencak Silat UM dan UB

\begin{tabular}{c|c|c|c|c}
\hline Hasil Analisis & Nilai F Tabel & Keterangan \\
\hline 0,088 & & 1,98 & F hitung $<$ F tabel $\alpha=0,05$ artinya Varian \\
Populasi Homogen
\end{tabular}

Berdasarkan hasil hasil analisis data uji homogenitas kecepatan tendangan antara atlet UKM pencak silat UM dan UKM pencak silat UB menunjukkan F hitung 0,088 lebih kecil dari $\mathrm{F}$ tabel $\alpha=$ 0,05 yaitu 1,98 artinya varian populasi homogen. Oleh karena itu, analisis uji-t dapat dilanjutkan.

\section{Hasil Analisis Uji-t} berikut.

Hasil analisis independent sample t-test disajikan pada Tabel 7 yang akan dipaparkan sebagai

Tabel 7. Independent Sample T-test kebugaran jasmani atlet UKM pencak silat UM dan UB

\begin{tabular}{cccc}
\hline $\begin{array}{c}\text { Hasil Tes Kebugaran } \\
\text { Jasmani }\end{array}$ & $\mathbf{T}$ & Df & Sig. (2-tailed) \\
\cline { 2 - 4 } & 2,034 & 58 &, 046 \\
\hline
\end{tabular}

Berdasarkan hasil analisis perbedaan rata-rata tingkat kebugaran jasmani kebugaran jasmani antara atlet UKM pencak silat UM dan UKM pencak silat UB menggunakan independent sample t-test adalah 0,046 . Nilai ini lebih besar dari signifikansi $\alpha=0,05$,menunjukkan yang berarti ada perbedaan yang signifikan.

Hasil analisis independent sample t-test disajikan pada Tabel 8 yang akan dipaparkan sebagai berikut. 
Tabel 8. Independent Sample T-test kebugaran jasmani atlet UKM pencak silat UM dan UB

\begin{tabular}{cccc}
\hline $\begin{array}{c}\text { Hasil Tes Kecepatan } \\
\text { Tendangan }\end{array}$ & $\mathbf{T}$ & df & Sig. (2-tailed) \\
\cline { 2 - 4 } & 2,164 & 58 &, 035 \\
\hline
\end{tabular}

Berdasarkan hasil analisis perbedaan rata-rata kecepatan tendangan antara atlet UKM pencak silat UM dan UKM pencak silat UB menggunakan independent sample t-test adalah 0,035 . Nilai ini lebih besar dari signifikansi $\alpha=0,05$,menunjukkan yang berarti ada perbedaan yang signifikan.

\section{Pengujian Hipotesis}

Berdasarkan hasil penelitian tentang perbedaan tingkat kebugaran jasmani atlet UKM pencak silat UM dan UKM pencak silat UB ditemukan bahwa t-hitung 2,034 dan t-tabel 1,67155. Oleh karena t-hitung 2,034 lebih besar dari t-tabel 1,67155, (t-hitung > t-tabel) maka Ho ditolak dan hipotesis kerja diterima yang menyatakan terdapat perbedaan yang signifikan perbedaan tingkat kebugaran jasmani atlet UKM pencak silat UM dan UKM pencak silat UB.

Berdasarkan hasil penelitian tentang perbedaan kecepatan tendangan atlet ukm pencak silat um dan ukm pencak silat ub ditemukan bahwa t-hitung 2,164 dan t-tabel 1,67155. Oleh karena t-hitung 2,164 lebih besar dari t-tabel 1,67155, (t-hitung $>$ t-tabel) maka ho ditolak dan hipotesis kerja diterima yang menyatakan terdapat perbedaan yang signifikan perbedaan kecepatan tendangan atlet ukm pencak silat um dan ukm pencak silat ub.

\section{PEMBAHASAN}

\section{Pembahasan Hasil Penelitian Tingkat Kebugaran Jasmani}

Berdasarkan hasil penelitian tingkat kebugaran jasmani antara atlet pencak silat Unit Kegiatan Mahasiswa Universitas Negeri Malang (UKM UM) dan atlet pencak silat Unit Kegiatan Mahasiswa Universitas Brawijaya (UKM UB) berupa multistage fitness tes atau bleep test dapat diketahui bahwa atlet pencak silat UKM UM mendapat $\mathrm{VO}_{2}$ Max nilai tertinggi yaitu 56,30 dan nilai terendah 42,20 jumlah keseluruhan tes dari masing-masing atlet/adalah 1541,3 dan mean adalah 51,41. Sedangkan atlet pencak silat UKM UB diketahui $\mathrm{VO}_{2} \mathrm{Max}$ nilai tertinggi yaitu 57,10 dan nilai terendah 42,20 , hasil keseluruhan tes dari masing-masing atlet adalah 1484,6 dan mean adalah 49,49.

Hasil tes kemudian dicocokkan dengan norma tes kebugaran jasmani dari 30 atlet pencak silat UKM UM dan 30 atlet pencak silat UKM UB. Atlet pencak silat UKM UM, tingkat kebugaran jasmani baik sekali sejumlah 13 atlet (43\%) dan kategori baik sejumlah 17 atlet $(56,7 \%)$. Sedangkan atlet pencak silat UKM pencak silat UB dengan tingkat kebugaran jasmani baik sekali sejumlah 9 atlet (30\%) dan kategori baik sejumlah 21 atlet $(70 \%)$.

Dari hasil analisis tes kebugaran jasmani atlet pencak silat UKM UM dan atlet pencak silat UB, terdapat perbedaan antara mean hasil tes kebugaran jasmani atlet pencak silat UKM UM dan atlet pencak silat UKM UB, dimana mean hasil tes kebugaran jasmani atlet pencak silat UKM UM 51,41 lebih tinggi dibandingkan mean hasil tes kebugaran jasmani atlet pencak silat UKM UB 49,49. Kemudian data hasil lapangan dianalisis menggunakan independent sample t-test, namun sebelumnya terdapat uji persyaratan yaitu uji normalitas menggunakan uji Kolmogorov-Smirnov dan uji homogenitas menggunakan uji Fisher.

Berdasarkan hasil analisis uji normalitas atlet pencak silat UKM UM diketahui dari uji one sample kolmogorov-smirnov $0,151>(\alpha=0,05)$ artinya data berdistribusi normal dan hasil analisis uji normalitas atlet pencak silat UKM UB diketahui dari uji one sample kolmogorov-smirnov $0,078>(\alpha=$ $0,05)$ artinya data berdistribusi normal. Berdasarkan hasil analisis uji homogenitas tes kebugaran jasmani atlet pencak silat UKM UM dan atlet pencak silat UKM UB menggunakan Uji Fisher menunjukkan hasil $\mathrm{F}$ hitung yaitu $0,463<\mathrm{F}$ tabel 1,98 . Dengan demikian varian data tes kebugaran jasmani atlet pencak silat UKM UM dan atlet pencak silat UKM UB bersifat homogen. Berdasarkan uji normalitas dan uji homogenitas, uji persyaratan untuk analisis uji-t terpenuhi yaitu data berdistribusi normal dan bersifat homogen. Oleh karena itu, analisis independent sample t-test dapat dilanjutkan. Berdasarkan hasil analisis independent sample t-test menunjukkan t-hitung 2,034 $>\mathrm{t}$-tabel $(\alpha$ $=0,05) 1,67155$, artinya terdapat perbedaan yang signifikan.

Berdasarkan hasil penelitian yang telah dilakukan, terdapat perbedaan yang signifikan kebugaran jasmani antara atlet pencak silat UKM UM dan atlet pencak silat UKM UB, dimana tingkat 
kebugaran jasmani atlet pencak silat UKM UM lebih baik dibandingkan kebugaran jasmani atlet pencak silat UKM UB. Irianto (2004: 2) menjelaskan bahwa kebugaran adalah kebugaran fisik (physical fitness), yakni kemampuan seseorang melakukan kerja sehari-hari tanpa timbul kelelahan yang berlebihan sehingga masih dapat menikmati waktu luangnya. Hal serupa juga dipaparkan oleh Wiarto (2015:55) kebugaran jasmani adalah kesanggupan dan kemampuan tubuh untuk melakukan penyesuaian (adaptasi) terhadap pembebasan yang diberikan kepadanya tanpa menimbulkan kelelahan yang berlebihan.

Kebugaran jasmani dipengaruhi oleh beberapa faktor. Faktor yang berasal dari dalam diri (factor internal) adalah sesuatu yang sudah terdapat dalam tubuh seseorang yang bersifat menetap, sedangkan faktor yang berasal dari luar diri (factor eksternal) adalah sesuatu yang sudah terdapat dari luar tubuh seseorang. Faktor internal adalah faktor bawaan yang tidak dapat diubah sedangkan faktor eksternal adalah faktor yang bisa mengubah tingkat kebugaran jasmani olahragawan. Berdasarkan hasil penelitian perbedaan tingkat kebugaran jasmani antara atlet pencak silat UKM UM dan atlet pencak silat UKM UB, peneliti menyimpulkan bahwa faktor yang mempengaruhi perbedaan kebugaran jasmani tersebut adalah faktor yang berasal dari luar tubuh yaitu latihan dan aktifitas fisik.

Menurut Harsono (2001:4) latihan kondisi fisik yang dilakukan secara sistematis, berencana, dan progresif, dan yang tujuannya ialah untuk meningkatkan kemampuan fungsional dari seluruh sistem tubuh agar dengan demikian prestasi olahragawan semakin meningkat serta peningkatan dalam kekuatan, kelentukan, stamina, kecepatan, dan lain-lain komponen kondisi fisik. Sedangkan menurut Irianto (2004:7-9) faktor yang mempengaruhi kebugaran jasmani yaitu makan, istirahat, dan olahraga. Olahraga adalah salah satu alternatifyang paling efektif dan aman untuk memperoleh kebugaran sebab berolahraga memiliki banyak manfaat antara lain manfaat fisik yaitu meningkatkan kebugaran, manfaat psikis yaitu lebih tahan terhadap stress, lebih mampu berkonsentrasi, dan manfaat sosial yaitu menambah percaya diri dan teman berinteraksi.

Menurut Nurhasan (2005:18-21) kebugaran jasmani dipengaruhi oleh 2 (dua) faktor utama yaitu faktor internal dan faktor eksternal. Faktor internal yaitu genetik, umur, dan jenis kelamin. Sedangkan faktor eksternal yaitu aktifitas fisik, status gizi, status kesehatan, kadar hemoglobin, kecukupan istirahat, dan kebiasaan merokok. Kemudian Giriwijoyo (2013:37) menjelaskan olahraga dilakukan untuk memelihara kesehatan dan atau meningkatkan derajat kesehatannya atau mereka yang ingin berprestasi dalam cabang olahraga. Menurut Menurut Kokkinos (2014:309) "physical fitness determined by several factor, including training, rest, psychological factors, and genetics". Yang diartikan oleh peneliti "kebugaran jasmani terdiri dari beberapa faktor termasuk latihan, istirahat, aktifitas fisik, dan genetik. Hoffman (2014:93) juga menjelaskan hal serupa yaitu "goals that are common to training include increasing muscle strength or size, improving sport performance, improving aerobic capacity, and improving body composition. Yang diartikan oleh peneliti tujuan umum latihan yaitu meningkatkan kekuatan otot, meningkatkan kinerja olahraga, meningkatkan kapasitas aerobic, dan meningkatkan komposisi tubuh.

\section{Pembahasan Hasil Penelitian Kecepatan Tendangan}

Berdasarkan hasil penelitian kecepatan tendangan jasmani antara atlet pencak silat Unit Kegiatan Mahasiswa Universitas Negeri Malang (UKM UM) dan atlet pencak silat Unit Kegiatan Mahasiswa Universitas Brawijaya (UKM UB) berupa tes tendangan lurus kanan dan kiri, tendangan sabit kanan dan kiri, tendangan samping kanan dan kiri, dapat diketahui bahwa atlet pencak silat UKM UM mendapat nilai tertinggi yaitu 27,33 dan nilai terendah 20,17 jumlah keseluruhan tes dari masingmasing atlet adalah 678,67 dan mean adalah 22,62. Sedangkan atlet pencak silat UKM UB diketahui nilai tertinggi yaitu 25,83 dan nilai terendah 17,17 , hasil keseluruhan tes dari masing-masing atlet adalah 644,57 dan mean adalah 21,49 .

Hasil tes kecepatan tendangan menunjukkan bahwa pada tes tendangan lurus, nilai atlet UKM pencak silat UM adalah 23,57 sedangkan nilai atlet UKM pencak silat UB adalah 22,20. Tes tendangan lurus kiri atlet UKM pencak silat UM adalah 21,90 sedangkan nilai atlet UKM pencak silat UB adalah 20,57. Tes tendangan samping kanan nilai atlet UKM pencak silat UM adalah 23,30 sedangkan nilai atlet UKM pencak silat UB adalah 21,93. Tes tendangan samping kiri nilai atlet UKM pencak silat UM adalah 22,00 sedangkan nilai atlet UKM pencak silat UB adalah 20,87. Tes tendangan sabit kanan nilai atlet UKM pencak silat UM adalah 23,20 sedangkan nilai atlet UKM pencak silat UB adalah 22,30. Tes tendangan sabit kiri nilai atlet UKM pencak silat UM adalah 21,77 sedangkan nilai atlet UKM pencak silat UB adalah 21,07. Jika dibandingkan dengan klasifikasi penilaian kecepatan tendangan maka atlet UKM pencak silat UM dengan kecepatan tendagan baik sekali sejumlah 6 atlet (20\%) dan kategori baik sejumlah 24 atlet (80\%); UKM pencak silat UB dengan kecepatan tendangan 
baik sekali sejumlah 1 atlet (3,3\%), kategori baik sejumlah 26 atlet (86\%) dan kategori cukup sejumlah 3 atlet $(10 \%)$.

Dari hasil analisis tes kecepatan tendangan atlet pencak silat UKM UM dan atlet pencak silat UB, terdapat perbedaan antara mean hasil kecepatan tendangan atlet pencak silat UKM UM dan atlet pencak silat UKM UB, dimana mean hasil tes kecepatan tendangan atlet pencak silat UKM UM 22,62 lebih tinggi dibandingkan mean hasil tes kecepatan tendangan atlet pencak silat UKM UB 21,49. Kemudian data hasil lapangan dianalisis menggunakan independent sample t-test, namun sebelumnya terdapat uji persyaratan yaitu uji normalitas menggunakan uji Kolmogorov-Smirnov dan uji homogenitas menggunakan uji Fisher.

Berdasarkan hasil analisis uji normalitas atlet pencak silat UKM UM diketahui dari uji one sample kolmogorov-smirnov $0,128>(\alpha=0,05)$ artinya data berdistribusi normal dan hasil analisis uji normalitas atlet pencak silat UKM UB diketahui dari uji one sample kolmogorov-smirnov $0,200>(\alpha=$ $0,05)$ artinya data berdistribusi normal. Berdasarkan hasil analisis uji homogenitas tes kebugaran jasmani atlet pencak silat UKM UM dan atlet pencak silat UKM UB menggunakan Uji Fisher menunjukkan hasil $\mathrm{F}$ hitung yaitu $0,088<\mathrm{F}$ tabel 1,98. Dengan demikian varian data tes kebugaran jasmani atlet pencak silat UKM UM dan atlet pencak silat UKM UB bersifat homogen. Berdasarkan uji normalitas dan uji homogenitas, uji persyaratan untuk analisis uji-t terpenuhi yaitu data berdistribusi normal dan bersifat homogen. Oleh karena itu, analisis independent sample t-test dapat dilanjutkan. Berdasarkan hasil analisis independent sample t-test menunjukkan t-hitung 2,164 >t-tabel ( $\alpha$ $=0,05) 1,67155$, artinya terdapat perbedaan yang signifikan.

Berdasarkan hasil penelitian yang telah dilakukan, terdapat perbedaan yang signifikan kecepatan tendangan antara atlet pencak silat UKM UM dan atlet pencak silat UKM UB, dimana tingkat kebugaran jasmani atlet pencak silat UKM UM lebih baik dibandingkan kebugaran jasmani atlet pencak silat UKM UB. Kecepatan tendangan sangat diperlukan dan dapat mempengaruhi penampilan seseorang baik pada saat menyerang maupun bertahan (Ihsan, dkk, 2018:124). Dalam pertandingan pencak silat teknik tendangan memiliki presentase yang cukup besar dalam posisi menyerang yaitu mencapai 47\% (Hariyono, 2017). Menurut lubis \& wardoyo (2016:198) kecepatan tendangan dalam pencak silat yang dapat di ukur yaitu tendangan lurus, tendangan sabit, dan tendangan samping.

\section{KESIMPULAN}

Berdasarkan hasil penelitian dan pembahasan, maka dapat diambil kesimpulan sebagai berikut: (1) tingkat kebugaran jasmani atlet pencak silat persaudaraan setia hati terate (PSHT) unit kegiatan mahasiswa (UKM) universitas negeri malang rata-rata termasuk dalam kategori baik, (2) tingkat kebugaran jasmani atlet pencak silat persaudaraan setia hati terate (PSHT) unit kegiatan mahasiswa (UKM) universitas negeri brawijaya rata-rata termasuk dalam kategori baik, (3) kecepatan tendangan atlet pencak silat persaudaraan setia hati terate (PSHT) unit kegiatan mahasiswa (UKM) universitas negeri malang rata-rata termasuk dalam kategori baik, (4) kecepatan tendangan atlet pencak silat persaudaraan setia hati terate (PSHT) unit kegiatan mahasiswa (UKM) universitas negeri brawijaya rata-rata termasuk dalam kategori baik, (5) terdapat perbedaan yang signifikan kebugaran jasmani antara atlet pencak silat persaudaraan setia hati terate (PSHT) unit kegiatan mahasiswa (UKM) universitas negeri malang dan universitas brawijaya, dimana tingkat kebugaran jasmani atlet pencak silat persaudaraan setia hati terate (PSHT) unit kegiatan mahasiswa (UKM) universitas negeri malang lebih baik dibandingkan kebugaran jasmani atlet pencak silat persaudaraan setia hati terate (PSHT) unit kegiatan mahasiswa (UKM) universitas negeri brawijaya, (6) terdapat perbedaan yang signifikan kecepatan tendangan antara atlet pencak silat persaudaraan setia hati terate (PSHT) unit kegiatan mahasiswa (UKM) universitas negeri malang dan universitas brawijaya, dimana kecepatan tendangan atlet pencak silat persaudaraan setia hati terate (PSHT) unit kegiatan mahasiswa (UKM) universitas negeri malang lebih baik dibandingkan kecepatan tendangan atlet pencak silat persaudaraan setia hati terate (PSHT) unit kegiatan mahasiswa (UKM) universitas negeri brawijaya. 


\section{DAFTAR PUSTAKA}

Djudin, T. 2013. Statistika Parametrik-Dasar Pemikiran dan Penerapannya dalam Penelitian. Yogyakarta: Tiara Wacana.

Giriwijoyo, S. 2013. Ilmu Faal Olahraga (Fisiologi Olahraga). Bandung: PT. Remaja Rosdakarya.

Hariyono, A. 2017. Developing A Performance Assesment of Kicks in The Competition Category of Pencak Silat Martial Arts. The Journal of Educational Development. Vol. 5 (2): 224-237.

Harsono. 2015. Kepelatihan Olahraga. Bandung: PT. Remaja Rosdakarya.

Ihsan, N., Yulkifli., \& Yohandri. 2018. Instrumen Kecepatan Tendangan Pencak Silat Berbasis Teknologi. Jurnal Sosioteknologi. Vol. 17 (1): 124-131.

Irianto, D. 2004. Pedoman Praktis Berolahraga untuk Kebugaran dan Kesehatan. Yogyakarta: Andi Yogyakarta.

Lubis, J. \& Wardoyo, H. 2014. Pencak Silat, (Edisi Kedua). Jakarta: Grafindo.

Lubis, J. \& Wardoyo, H. 2016. Pencak Silat, (Edisi Ketiga). Jakarta: Grafindo.

Quadratullah, M. F. 2014. Statistika Terapan-Toeri,contoh kasus, dan Aplikasinya dengan SPSS. Yogyakarta: CV Andi Offset.

Rahayuni, K. 2014. PencakSilat. Malang: UM Press.

Sugiyono. 2014. Metode Penelitian Pendidikan Pendekatan Kiuantitatif, Kualitatif, dan $R$ \& D. Bandung: Alfabeta.

Undang-undang Repulik Indonesia No.3 Tahun 2005 tentang Sistem Keolahragaan Nasional. (Online), (http://www.unsrat.ac.id/uu/uu_3-05.htm), diakses pada 15 Desemer 2018.

Wardani, D. 2017. Perbedaan Tingkat Kebugaran Jasmani antara Olahragawan Pencak Silat FIK dan Olahragawan UKM Pencak Silat Universitas Negeri Malang. Malang. FIK UM (Skripsi).

Wiarto, G. 2015. Panduan Berolahraga untuk Kesehatan dan Kebugaran. Yogyakarta: Graha Ilmu.

Winarno, M. E. 2017. Metodologi Penelitian dalam Pendidikan Jasmani. Malang: Media Cakrawala Utama Press. 